\title{
JOINT PROJECTS - EFFECTIVE TOOLS FOR FACILITATING THE DEVELOPMENT OF GLOBAL EDUCATIONAL PROCESSES
}

\author{
Darejan Tvaltvadze \\ Professor, Georgia \\ Irina Gvelesiani \\ Associate Professor, Georgia
}

\begin{abstract}
Contemporary educational processes have to be in tune with the increasing global tendencies. All the world countries strive to unite under the umbrella term "global village", which implies interconnected and almost unified political, economic, cultural, juridical and even educational spheres of life. Special grave challenges are faced by contemporary postSoviet countries. They have to undergo the post-communist era, to struggle for the survival via radical correctional policy and to interweave globally oriented as well as capitalistically oriented strategies. The greatest challenge is posed to the educational sphere. Many post-Soviet higher educational institutions strive to join the European Higher Education Area. The given institutions try to interflow for the genuine overcoming of the existed "insurmountable" barriers. They consolidate collaboration and cooperation on different research and educational programs. Many newly-created joint projects appear and "play a key role in creating the rightful architecture of modern society. A central point in this process is the enquiry to identify... most urgent problems in national educational systems" (Pourtskhvanidze, 2016), to determine the strategies of functioning in multilingual society and to create a universal educational model of post-communist area via finding a balance between national and worldly.

The given paper presents innovative university projects, which belong to two different worlds: the highly developed capitalistic world (Italian international project "Linguaggi e attività Produttive,,) and post-Soviet "capitalistically-directed" space (Georgian-Ukrainian "DIMTEGU”). "Linguaggi e attività Produttive, and "DIMTEGU" have different nature and individual ways of development. However, both of them present innovative mechanisms of the preservation of multiculturalism and plurilingualism. The promotion of multiculturalism, facilitation of the preservation of plurilingualism, introduction of multilingual teacher education, development of appropriate curricula and teaching materials, suggestion of the fruitful ways of the adaptation to the global challenges - these are the major issues of our paper and crucial problems of today's educational world.
\end{abstract}

Keywords: globalization, multiculturalism, plurilingualism/multilingualism, project.

(C) Rēzeknes Tehnologiju akadēmija, 2017

http://dx.doi.org/10.17770/sie2017vol1.2425 


\section{Introduction}

"If climate change is the key process in the natural world impacting on sustainable development, then globalisation is the parallel process in the human world, creating both opportunities for, and barriers to, sustainable development..." ("Globalisation," n. d.). Globalization has accelerated since the $50 \mathrm{~s}$ of the $20^{\text {th }}$ century and has significantly effected almost all spheres of life. Nowadays, all the world countries strive to unite under the umbrella term "global village", which implies interconnected and almost unified political, economic, cultural, juridical and educational spheres of life. Scholars even single out a term "cultural globalization", which denotes "the connections among languages, ways of living, and fears of global homogeneity through the spread of North American and European languages and culture" ("What is globalization?" n. d.). However, on the background of a sustainable tendency of homogeneity and uniformity, a cultural diversity acquires a global value. It becomes a prerequisite of a lingual diversity via promoting the revitalization of the world languages and via fostering their intense usage. All these processes are partially monitored by the global educational processes promoting internationalizing policies. The given policies are associated with a great variety of international programs, grants, strategies, which are oriented on the preservation of multiculturalism and plurilingualism. Promotion of multiculturalism, facilitation of the preservation of plurilingualism, introduction of multilingual teacher education, development of appropriate curricula and teaching materials, suggestion of the fruitful ways of the adaptation to the global challenges - these are the major issues of our paper and crucial problems of today's world. Our research is oriented on the presentation of innovative strategies which have been carried out at several universities by means of the implementation of "DIMTEGU" (the project initiated by Ivane Javakhishvili Tbilisi State University) and "Linguaggi e attività Produttive," (the project initiated by the University of Bologna). Significant future-oriented (planned to be implemented in future) policies are also revealed and discussed.

\section{Joint Projects}

„Internationalisation of higher education is the process of integrating an international/intercultural dimension into the teaching, research and service functions of the institution" (Wit, 1998). The essence of internationalization is mainly associated with a great variety of mobility/exchange programs, foreign grants, market-oriented strategies, etc. The less attention is paid to those multilateral projects, which sometimes become milestones of the internationalization of higher education via merging foreign and local or via detaching national and intercultural. These merging and detaching processes 
reflect the contemporary global demands and highlight the importance of internationally oriented projects. Their credit is becoming higher than that of mobility programs, because foreign education may ignite the confrontation with one's own culture.

The given paper presents innovative university projects, which belong to two different worlds: the Italian international project "Linguaggi $\boldsymbol{e}$ attività Produttive,, represents the highly developed capitalistic world, while the Georgian-Ukrainian "DIMTEGU" belongs to the post-Soviet "capitalisticallydirected" space. "Linguaggi $\boldsymbol{e}$ attività Produttive, and "DIMTEGU" have different natures and individual ways of development. However, they present innovative mechanisms of the preservation of multiculturalism and plurilingualism. The given projects have a significant impact on teaching processes, because "plurilingualism defines the language policy of the Council of Europe, and is a fundamental principal of language education policies in Europe and elsewhere in the world" (Grigule, 2011).

"Linguaggi e attività Produttive,, has a twofold (linguistic-juridical) nature and aims at comparing the regulation of the domain $\boldsymbol{H S W}$ (Health and Safety at Work) by legal systems of Italy, UK, Germany and France. The analyses given in the project are not limited to the linguistic level. They are oriented on the cultural differences and on the constant evolution of European legislation. The major essence of "Linguaggi e attività Produttive,, lies in the fact that it aims at providing a knowledge base containing three independent components:

- "a quadrilingual (Italian, English, French, German) terminological database;

- a library of sources, i.e. a collection of legal texts on HSW for different systems involved" ("EOHS Term," n. d.).

- "a collection of concept diagrams, i.e. graphic representations of the domain structure which can help the users get a clearer view of the relations existing between concepts" ("EOHS Term," n. d.).

The uniqueness of "Linguaggi e attività Produttive,, lies in the originality of "concept mapping" (creation of concept diagrams) initiating the digitalization of the linguistic data. The same unique method of terminological studies was presented at the end of the $20^{\text {th }}$ century by Georgian Professor Manana Chirakadze and a group of her followers. At this moment, there is a tendency of the creation of a new project at Tbilisi State University. It will be oriented on the building of a multilingual corpus comprising at least five languages (Georgian, Russian, English, French, German) and different juridical domains: law of succession, trust law, property law, etc. The process of the creation of the project will present some aspects of the Italian experience and a mixture of purely Georgian elements (the creation of thesauruses, new Georgian lexical units, etc.). It will comprise the following major stages: 
- Gathering the concepts related to a particular semantic field i.e. the creation of a concept-base;

- The creation of concept maps ("derivational trees") for different languages;

- Nomination of each concept with an appropriate lexical unit i.e. the creation of a term-base for each language;

- Creation of a thesaurus for each term-base;

- Comparative analysis of the data of different languages i.e. investigation of similarities and differences of single concepts and relationships between the items of "derivational trees" representing different languages;

- Finding out gaps of a term-base of the Georgian language according to the data of other languages;

- $\quad$ Filling gaps - filling each gap of a term-base with a newly-created Georgian lexical unit;

- Definitions - writing definitions of newly-created terms;

- Attachment of Georgian, Russian, English, French and German legal texts for the identification of the terms of a term-base;

- Creation of the multilingual dictionary comprising newly-created Georgian items.

The implementation of the given project will have important outcomes. The uniqueness of its methodology lies in the originality of "concept mapping" (derivational tree) initiating the digitalization of the linguistic data. Each unit of the corpus represents a strongly-defined element of a particular semantic field and becomes easily identifiable during the comparison of the data of different languages. Such system of identification acquires the greatest importance during the digital era - the world visibility of the Georgian language is increased and its enrichment with newly-created terms raises its value, international circulation and competitiveness. Moreover, "corpus linguistics looks at language from a social perspective" (McEnery \& Hardie, 2012). It focuses on meaning. "Meaning is what is being verbally communicated between members of discourse society" (McEnery \& Hardie, 2012). For this reason, the implementation of corpus-based studies and projects becomes the latest trend in Georgia. It plays an utmost role in the development of Georgian lingual landscape, which strives to reach global interconnectedness via the maintenance of individuality.

The greatest attention must be paid to the project DIMTEGU ("Development and Introduction of Multilingual Education Programs at Universities of Georgia and Ukraine"), which was initiated and coordinated by Ivane Javakhishvili Tbilisi State University during 2012-2016. The major goal of the given project was the support of the multilingual education reform in Georgia and Ukraine through the 
multistage activities. The given activities considered particular prerequisites, for instance: "the establishing of peculiar awareness to multilingualism as the way of life; The recovering of deficits and needs of the certain education system regarding multilingualism and adaptation of given social reality in it; The creation of certain educational model, which is fitted within the language relations of the society..." (Pourtskhvanidze, 2016). The consideration of the given prerequisites resulted in the creation of the following multifaceted strategies of the development of the project:

1. Creation of syllabi and frame curriculum for multilingual education programs;

2. Piloting and introduction of $\mathrm{BA}$ and $\mathrm{MA}$ multilingual education programs;

3. Development of the Moodle platform and web-sites for the given courses;

4. Equipping higher educational institutions with sufficient, up-to-date teaching materials and equipment;

5. Organization of trainings (for the members of the faculties) considering:

- $\quad$ "Module I: Teaching methods;

- $\quad$ Module II: Development of syllabus;

- Module III: Multilingual/Multicultural Education" ("DIMTEGU," n. d.);

6. The equipment of libraries of Georgian and Ukrainian universities with computers and modern teaching materials;

7. Translation of 20 textbooks on multilingual and international education into the Georgian and Ukrainian languages;

8. Providing public schools of Georgia and Ukraine with qualified teachers (preparation and training of 400 in-service teachers from Georgia and Ukraine), etc.

Besides the above-mentioned strategies, we have to focus on one of the major outcomes of DIMTEGU - the facilitation of the implementation of multilingual education in Georgia. Generally, "multilingual education refers to the use of two or more languages as mediums of instruction, as defined by UNESCO" (Schulter, 2011). Multilingual schools have already become a feature of Europe's diverse and complex linguistic landscape. The same cannot be said about Georgia. This country lacks subject teachers at multilingual schools, which are located in the regions compactly settled by the ethnic minorities (Armenians and Azerbaijanis). DIMTEGU has tried to solve the given problem - it has implemented one-year program (60 ECTS) of multilingual education, which trains functioning bilingual teachers of non-Georgian schools. An additional priority of one-year program is training graduates with BA degree and giving 
them an opportunity of working at multilingual schools (Georgia's current legislation does not allow citizens with BA degree to occupy a teacher's position) of remote villages. Therefore, one of the major outcomes of DIMTEGU is the increase of the quality of teacher education, which "is among one of the topical keywords in political discourse, scientific research and implementation process of teaching practices" (Bethere et al., 2016).

It is also worth mentioning, that during the last decades, there has been almost no experience in the field of multilingual education in Georgia and Ukraine. DIMTEGU has brought positive changes in this respect. Besides facilitating progressive educational strategies, it founded "International Electronic Journal of Multilingual Education" (IJME), which is oriented on advancing knowledge of theory, research and practice in the fields of multilingual and multicultural education and language acquisition. The journal supports dissemination of knowledge about bilingual education, facilitates effective introduction of multilingual educational programs in general educational system and promotes the development of bilingual education as an interdisciplinary scientific field. IJME is indexed in different international databases. The given fact has an outstanding importance, because indexing has become the latest tendency in post-Soviet Georgia, which strives to promote advanced western strategies.

An additional significance of DIMTEGU lies in the fact, that all the activities carried out in Georgia and Ukraine have been monitored by the prominent European universities (Goethe University of Frankfurt, Freiburg University of Education, University of Latvia, Vilnius University). Moreover, the Georgian and Ukrainian teachers and staff were trained by the representatives of the same higher education institutions. During the training courses the trainees got acquainted with the latest European achievements in the fields of bilingualism, multilingual education, overall structure of effective curricula and syllabi, student-centered and problem-based teaching methods, usage of technologies in teaching processes, administration of diversity and multiculturalism in education, etc. Consideration and comprehension of European achievements mean a lot for the post-Soviet reality, because the given attitude to the implementation of the educational reforms leads to proper, rapid and well-defined outcomes. The results of DIMTEGU have already been successfully implemented in Georgian/Ukrainian higher education institutions (BA and MA programs and curriculum, libraries and classrooms equipped with up-to-date teaching materials and equipment...) and secondary schools (teaching materials and welltrained teachers ready for the usage of innovative methods of teaching). In Georgia the major beneficiaries of multilingual educational programs are Armenian and Azerbaijani citizens who live in remote villages and who have a poor knowledge of the state language. Acquisition of the Georgian language is a 
prerequisite of their successful integration into the Georgian public life. Therefore, the main beneficiaries of the programs created by DIMTEGU will maintain their language and ethnicity on the background of integrational processes. This is one of the unique examples of the preservation of plurilingualism and its consequent multiculturalism, because "language, like culture, is community specific and is intricately interwoven with the culture it represents" (Pai, 2005). Besides a vivid attempt of the maintenance of the multiethnicity of Georgia's population, DIMTEGU "struggles" for the raise of the value, local circulation and competitiveness of the Georgian language. Moreover, it pays a particular attention "to the field of teacher education that is considered as one of the most important factors influencing the quality of education" (Bethere et al., 2016). The given threefold nature doubles the merits of DIMTEGU.

\section{Conclusions}

"Internationalization in higher education is an inevitable result of the globalized and knowledge-based economy of the $21^{\text {st }}$ century" (Altbach \& Teichler, 2001). It "invades" majority of educational institutions of the world. The gravest challenges are faced by contemporary post-Soviet universities, which undergo the post-communist era, struggle for the survival via radical correctional policy and interweave globally and capitalistically oriented strategies. Tbilisi State University is one of the post-Soviet higher educational institutions. It consolidates collaboration and cooperation on different research and educational programs. Tbilisi State University relies on the implementation of joint international projects, which foster the fruitful ways of the adaptation to the global challenges. The above discussed DIMTEGU promotes the reformation and modernization of post-Soviet higher educational institutions, facilitates the preservation of multilingualism, introduces multilingual teacher education strategies, fosters the development of appropriate curricula and teaching materials, etc. In contrast to DIMTEGU, the planned project of multilingual corpus is mainly oriented on the enrichment and popularization of the Georgian language. It presents innovative mechanisms of the preservation of plurilingualism and multiculturalism, because the enrichment of any language prolongs the existence of its related culture. Moreover, the implementation of corpus-based studies and projects becomes the latest trend in Georgia. It plays an utmost role in the development of Georgian lingual landscape, which strives to reach global interconnectedness via the maintenance of individuality.

Therefore, the highlighted projects can serve as exemplary and useful models of progress for those post-Soviet universities of the world, which strive to create universal educational-research models of post-communist area via finding a 
balance between national and worldly. The major value of the projects is their upto-date character, which is revealed in the meeting the crucial requirements of the Council of Europe (the principles presented in the preamble to Recommendation R (82) 18 of the Committee of Ministers):

- "rich heritage of diverse languages and cultures in Europe is a valuable common resource to be protected and developed... major educational effort is needed to convert that diversity from a barrier to communication into a source of mutual enrichment" (Recommendation No. R (82) 18 of the Committee of Ministers to Member States Concerning Modern Languages, 1982).

\section{Summary}

Today the world countries strive to unite under the umbrella term "global village", which implies interconnected and almost unified spheres of life. The gravest challenges are faced by the contemporary post-Soviet educational spaces. Internationalization and modernization - these are the major tendencies, which have to be in tune with the preservation of plurilingualism and multiculturalism. The discussion of DIMTEGU clearly reveals that Tbilisi State University tries to keep up-to-date on the recent tendencies via implementing international projects serving as effective tools for facilitating the development of global educational processes. Besides already-implemented projects, there is the orientation on the creation of a multilingual corpus comprising several languages and different juridical domains. These tendencies reveal the development of the Georgian higher educational space and its aspiration towards the establishment of westernoriented strategies. All the gained results serve as significant tools for the maintenance of plurilingualism and multiethnicity. Georgian models of joint projects can become exemplary samples for other higher education institutions of post-Soviet area, because they represent "newly-built bridges" between local and global. Moreover, these projects raise the competitiveness of post-communist space via effective promotion of global educational processes.

\section{References}

Altbach, P., \& Teichler, U. (2001). Internationalization and Exchanges in a Globalized University. Journal of Studies in International Education, 5, 5-25.

Bethere, D., Pavitola, L., \& Usca, S. (2016). Building Pedagogical Relationships in Diverse Educational Environments. Journal of Teaching and Education, 05 (01), 263-274.

DIMTEGU. (n. d.). Downloaded from http://dimtegu.tsu.ge/

EOHS Term. (n. d.). Downloaded from http://eohsterm.org/sections/project/index.php

Globalisation. (n. d.). Downloaded from http://www.unesco.org/education/tlsf/mods/theme_c/ mod18.html 
Proceedings of the International Scientific Conference. Volume I, May $26^{\text {th }}-27^{\text {th }}, 2017.402-410$

Grigule, L. (2011). Problems and Challenges of Teaching State Language in the Implementation Process of Multilingual Education. Proceedings of International Scientific Conference Issues of State Language Teaching: Problems and Challenges, 258266.

McEnery, T., \& Hardie, A. (2012). Corpus Linguistics: Method, Theory and Practice. Cambridge: Cambridge University Press.

Pai, P. (2005). Multilingualism, Multiculturalism and Education: Case Study of Mumbai City. Proceedings of the $4^{\text {th }}$ International Symposium on Bilingualism, 1794-1806.

Pourtskhvanidze, Z. (2016). DIMTEGU - Some Prerequisites of International Education Project. International Journal Multilingual Education, 8, 1-5.

Recommendation No. R (82) 18 of the Committee of Ministers to Member States Concerning Modern Languages. (1982). Downloaded from https://wcd.coe.int/com.instranet.Instra Servlet?command $=$ com.instranet.CmdBlobGet\&InstranetImage $=601630 \&$ SecMode $=1$ $\&$ DocId $=676400 \&$ Usage $=2$

Schulter, B. (2011). Multilingual Education and the Rights of the Child. Proceedings of International Scientific Conference Issues of State Language Teaching: Problems and Challenges, 238-247.

What is globalisation? (n. d.). Downloaded from http://www.unesco.org/education/tlsf/mods/ theme_c/mod18.html?panel=3\#top

Wit, H. (1998). Rationales for Internationalization of Higher Education. Millenium, 11. 